\title{
Academic publishing in Sweden threatened by withdrawal of support
}

In November 20I3 the news came that the board of the Swedish Research Council (Vetenskapsrådet, VR) had decided on a gradual withdrawal of financial subsidies to more than 30 of Sweden's scholarly journals in the humanities and social sciences. The decision detonated like a bomb. A withdrawal of subsidies to the journals would mean that most channels for scholarly publication in the Swedish humanities and social sciences would disappear.

VR is a Swedish state authority with a commission from the Swedish government to support and promote research throughout the scholarly field. The authority states four reasons for its decision to terminate the publication subsidies (Björk 20I3):

- The publishing subsidies are small [3.5 million Swedish kronor per year, equivalent to 0.07 per cent of all the research funding granted by the authority $-E d$.] and according to VR this consumes too much of the authority's resources to administer in proportion to the small size of the grants

- VR believes that open access has changed the conditions for scholarly publishing, so that journals survive by charging fees of researchers who wish to publish their work

- VR considers that subsidizing the publication of scholarly journals is not part of the authority's task of supporting Swedish research

- VR considers that the survival of scholarly journals is not the responsibility of the authority.

The proposal has provoked massive criticism. National media have criticized and debated this preposterous move by VR, Swedish universities 
have expressed unanimous disapproval of the decision, and the editors of the journals concerned, including myself, have criticized the decision and initiated a discussion about solutions to the problems created by VR.

There are powerful quality arguments for the existence of both nationally and internationally oriented Swedish journals for publishing research findings in the humanities and social sciences. A Swedish research discourse requires forums for debate in Swedish for Swedish-speaking researchers. It also requires an internationalization in which debate is carried on in other languages (the current international trend means that this is predominantly English). It also requires journals which invite national and international scholars to discuss research in the humanities and social sciences from different standpoints than today's dominating North American and British positions. All this can be found today in Swedish scholarly journals in the humanities and social sciences.

It is remarkable that the VR board has taken this decision to end support for this diverse range of scholarly publications without first conducting a thorough inquiry and consequence analysis. Citing reasons such as internal administrative problems and ill-founded claims about open-access publishing does not exactly boost one's confidence in the way the authority has acted.

VR has for a number of years made increasingly rigid demands of the publishers of Swedish scholarly journals. By demanding professionalism in the form of a thorough peer-review process, the establishment of international advisory boards and a well-functioning open-access system, the research council has hitherto helped to raise the quality of Swedish scholarly journals in the humanities and social sciences. In an article in the New York Times on I December 20I3 the journalist Ella Delany gives a well-informed description of how the humanities globally are increasingly threatened by decreased funding and political attacks. VR's actions - this swing from making higher demands that lead to positive stimulation to a demand for termination - is unfortunately in line with these global trends.

A virtually unanimous demand from Swedish humanities and social sciences is that VR must take a step backward and start an independent, and totally unprejudiced analysis of how the financial subsidies for Swedish scholarly journals can be continued in times when VR does not think that this support is among the tasks of the authority.

VR wants to draw up a termination plan (Björk 20I3). This is insufficient. What is needed is a stimulation plan. It is to be hoped the authority heeds the criticism and actually formulates such a plan, outlining how VR can transfer the responsibility it has today, but does not wish to have in the future, to someone who believes that publication support 
for the scholarly journals in the humanities and social sciences is an important future responsibility to take.

The editorial board of Current Swedish Archaeology will, of course, keep readers informed of what is happening in this matter.

Anders Högberg One of two editors for Current Swedish Archaeology

\section{Reference}

Björk, J. 20I3. Vi vill bidra till bra spridning av forskningsresultat. Curie 2 December 2013. Vetenskapsrådet. [online] Available at: <http://www.tidningencurie.se/22/ debatt/debatter/2OI3-I 2-O2-vi-vill-bidra-till-bra-spridning-av-forskningsresultat. html> [accessed ro December 20I3]. 